\title{
Nilai-Nilai Pendidikan Islam Dari Ornamen Arsitektur Masjid Assu’ada Waringin
}

\author{
Husin \\ hafizhihusinsungkar@gmail.com \\ Nor Anisa \\ noranisabk30@gmail.com \\ Sekolah Tinggi Ilmu Alquran (STIQ) Rakha Amuntai, Kalimantan Selatan, Indonesia
}

\begin{abstract}
Abstrak
Masjid Assu'ada lebih dikenal dengan sebutan "Masjid Lancip" merupakan salah satu masjid tertua yang ada di Kabupaten Hulu Sungai Utara, tepatnya di Desa Waringin, Kecamatan Haur Gading yang selama ini tidak banyak diketahui masyarakat Kalimantan Selatan lantaran lokasinya yang agak terpencil. Masjid Assu'ada telah masuk cagar budaya, namun belum banyak yang mengetahui sejarah masjid dan bagaimana nilai-nilai pendidikan Islam yang terdapat pada ornamen arsitektur masjid tersebut. Perkembangan zaman yang berubah telah mengiringi perkembangan Masjid Assu'ada dan mengalami beberapa kali renovasi, namun bentuk dan tiang masih tetap dipertahankan. Penelitian ini dilakukan bertujuan untuk menjelaskan bagaimana nilai-nilai pendidikan Islam yang terdapat pada ornamen arsitektur Masjid Assu'ada dan bagaimana isi pesan tersirat pada bangunan masjid tersebut. Jenis penelitian ini merupakan penelitian deskriptif dengan metode kualitatif. Subjek dalam penelitian ini adalah sebagian pengelola masjid dan sesepuh yang dianggap lebih mengetahui tentang masjid Assu'ada. Prosedur pengumpulan data dilakukan melalui observasi, wawancara, dan dokumentasi. Analisis data terdiri dari reduksi data, penyajian data, dan penarikan kesimpulan. Hasil penelitian menunjukkan bahwa nilai-nilai pendidikan Islam yang ingin disampaikan ialah, nilai ketauhidan atau akidah, nilai ibadah atau syariat, dan nilai muamalah atau akhlak. Nilai-nilai tersebut disisipkan melalui ornamen arsitektur dan bagian-bagian yang terdapat pada masjid Assu'ada.
\end{abstract}

Kata kunci : Nilai-Nilai, Pendidikan Islam, Ornamen Arsitektur, Masjid Assu'ada

\section{PENDAHULUAN}

Masyarakat Banjar di Kalimantan Selatan identik dengan agama Islam. Identitas itu tidak hanya tercermin dari kenyataan bahwa Islam merupakan agama mayoritas, namun juga terdapat banyaknya tempat ibadah berupa masjid, langgar (surau), dan mushola. Keberadaan tempat ibadah itu sejalan dengan sejarah masuk dan tersebarnya agama Islam di Kalimantan Selatan. Dimana umat Islam berada, maka dibangunlah masjid sebagai tempat ibadah shalat lima waktu, shalat Jum'at, shalat hari raya, dan kegiatan ibadah lainnya. ${ }^{1}$ Banyak hal yang digunakan para tokoh untuk menyebarkan

1 Wajidi, "Ragam Arsitektur Masjid Tradisional Banjar Kalimantan Selatan dan Makna Simbolisnya,” Jurnal Kebijakan Pembangunan Vol. 12, No. 2 (Desember 2017), h. 149.

Al Qalam: Jurnal Ilmiah Keagamaan dan Kemasyarakatan

Vol. 15, No. 1, Januari-Juni 2021 
agama Islam. Simbol-simbol dan upacara-upacara digunakan sebagai media syiar ajaran Islam. Tidak terkecuali bangunan masjid, selain dijadikan tempat ibadah, masjid pada zaman penyebaran Islam juga dijadikan syiar pendidikan Islam. Banyak nilai-nilai pendidikan Islam dari ornamen arsitektur ataupun simbol-simbol yang ada di masjid. ${ }^{2}$

Indonesia merupakan negara yang kaya akan kebudayaan. Berbagai bangsa dan suku ada di Indonesia, sehingga terdapat beraneka ragam jenis karya seni yang dihasilkan. Salah satunya adalah ornamen atau ragam hias. Ragam hias merupakan bagian seni rupa yang akrab dengan kehidupan budaya. ${ }^{3}$ Menurut Gustami ornamen adalah komponen produk seni yang ditambahkan atau sengaja dibuat untuk tujuan sebagai hiasan. ${ }^{4}$ Ornamen adalah salah satu elemen penting yang hampir tidak bisa ditinggalkan ${ }^{5}$ Keberadaan ornamen sebagai penghuni bidang kosong, secara estetik merupakan sebuah irama harmonis yang selalu dikombinasikan untuk mengurangi kejenuhan. ${ }^{6}$ Ornamen berupa komponen produk seni yang ditambahkan atau sengaja dibuat untuk tujuan hiasan. Di samping tugasnya menghiasi yang implisit menyangkut segi-segi keindahan, misalnya untuk menambah indahnya suatu barang sehingga lebih bagus dan menarik, akibatnya mempengaruhi pula dari segi penghargaannya, baik dari segi spiritual maupun material/ finansialnya. ${ }^{7}$ Pada setiap penampilan ornamen dari suatu karya arsitektur dapat dikenal unsur yang tidak dapat dipisahkan dari rasa keindahan manusia. Pemakaian ornamen biasanya terselip suatu pesan tersendiri dan merupakan latar belakang budaya yang ada pada saat itu. ${ }^{8}$ Nilai estetis dalam peradaban manusia diungkapkan melalui perwujudan berbagai karya seni, termasuk seni bangunan dan ornamennya. ${ }^{9}$ Seni bangunan bukan sekadar pernyataan bentuk atau struktur semata, namun juga berperan sebagai institusi budaya, pencerminan sistem nilai dan sosial dari suatu konsep dan gagasan yang identik dengan corak kehidupan masyarakat pendukungnya. ${ }^{10}$ Dimana segala bentuk peradaban manusia dapat dibaca secara otentik dari ornamen yang ditinggalkan pada artefak- artefak yang ada. Seperti halnya dengan arsitektur atau bangunan yang dapat dinyatakan sebagai penyangga utama ornamen. Nilai arsitektur sebuah bangunan selain muncul melalui bentuk juga dapat dilihat melalui penerapan ornamen yang menyertai keberadaannya secara visual. ${ }^{11}$

\footnotetext{
${ }^{2}$ Rahmad Sholikhin, Skripsi "Nilai-Nilai Pendidikan Islam dalam Gaya Arsitektur Masjid Pathok Negoro Sulthoni dan Eksistensinya Pada Remaja Sekitar di Plosokuning Yogyakarta” (Yogyakarta: Fakultas Ilmu Agama Islam Universitas Islam Indonesia, 2020), h. 1.

${ }^{3}$ Eko Roy Ardian Putra, Skripsi "Makna Simbolis pada Ragam Hias Masjid Mantingan di Jepara” (Surakarta: Institut Seni Indonesia, 2018), h. 1.

${ }^{4}$ Gustami, Nukilan Seni Ornamen Indonesia (Yogyakarta: Institut Seni Indonesia, 2008), 4.

5 Sri Sundari dan Yulimarni, "Estetik Ornamen Masjid di Kota Padang," Jurnal Seni Desain Dan Budaya Vol. 5, No. 2 (2020), h. 3.

${ }^{6}$ Sundari dan Yulimarni, 2.

7 Mirda Aryadi, Asril S, dan Febri Yulika, "Ornamen Masjid Asasi Sigando Kota Padangpanjang,” Gorga : Jurnal Seni Rupa Vol. 09 No. 01 (Juni 2020), h. 64.

8 Bambang Supriyadi, "Kajian Ornamen pada Mesjid Bersejarah Kawasan Pantura Jawa Tengah," ENCLOSURE : Jurnal Ilmiah Perancangan Kota dan Permukiman Vol. 7 No. 2 (2018), h. 107.

${ }^{9}$ Supatmo dan Syafii, "Nilai Multukultural Ornamen Tradisional Masjid-Masjid Warisan Para Wali di Pesisir Utara Jawa," Jurnal Imajinasi Vol. XIII No. 2 (Juli 2019), h. 2.

10 Nunung Dewi Alfirah, Fadhilah Aliyyah Rasyid, dan Wasilah, "Seni Hias Bangunan Bersejarah Masjid Lompoe Urwatul Wudska Maros," TIMPALAJA Jurnal Dosen dan Mahasiswa Arsitektur Volume 1, Nomor 2 (2019), h. 123.

${ }^{11}$ Sundari dan Yulimarni, "Estetik Ornamen Masjid di Kota Padang," h. 2.
}

Al Qalam: Jurnal Ilmiah Keagamaan dan Kemasyarakatan

Vol. 15, No. 1, Januari-Juni 2021 
Arsitektur merupakan cabang atau bagaian dari seni rupa yang termasuk dalam karya tiga dimensi dan menjadi kebutuhan manusia. ${ }^{12}$ Istilah "arsitektur" berasal dari Bahasa Yunani, yaitu dari suku kata "arkhe" yang berarti "asli" dan suku kata "tekton" yang berarti "kokoh". Pengertian awalnya, "arsitektur" dapat diartikan sebagai sesuatu yang asli untuk membangunan secara kokoh menurut Wangsadinata dalam bukunya Risca Damayanti dan selanjutnya menurut Sidharta mengungkapkan bahwa arsitektur adalah seni guna yang khusus, karena aristektur merupakan kerangka ruang untuk kehidupan. ${ }^{13}$ Arsitektur Islam merupakan salah satu keilmuan yang mempelajari tentang arsitek yang sesuai pada nilai-nilai Islam yang bersumber pada Alquran. Alquran tentunya merupakan dasar bagi pengembangan berbagai bidang keilmuan, salah satunya keilmuan arsitektur. Wujud arsitektur yang muncul sebagai hasil kreasi seorang arsitek, yang melambangkan nilai-nilai Islam. ${ }^{14}$ Arsitektur Islam adalah arsitektur yang di dalamnya nilai Islam diterapkan, seperti nilai penghambaan terhadap Allah melalui desain bangunan, nilai kesederhanaan, nilai keadilan, nilai pengakuan terhadap hak orang lain sedangkan arsitektur Islam lebih mengedepankan pada nilainilai keIslaman yang bersumberkan pada Alquran dan Hadits. ${ }^{15}$ Faktor yang mempengaruhi corak atau ragam arsitektur budaya Islam adalah kebudayaan, teknologi, dan iklim setempat. Islam sebagai agama Rahmatan lil 'alamin (agama rahmat bagi seluruh alam), menempatkan nilai-nilai Islami dalam setiap sendi kehidupan, tidak merusak, penuh rahmat, dan cinta kehidupan. Perwujudan arsitektur Islami merupakan ikhtiar muslim untuk menjamin keberadaan nilai-nilai Islami dalam wujud elemen fisik agar selalu sesuai dengan pedoman Islam. ${ }^{16}$ Salah satu karya arsitekur Islam yang ada di Indonesia adalah masjid.

Masjid merupakan sebuah bangunan atau tempat orang muslim untuk melakukan ibadah shalat. Keberadaan masjid di lingkungan masyarakat Islam tidak hanya berfungsi sebagai tempat ibadah, tetapi juga digunakan untuk menanamkan pendidikan Islam. ${ }^{17}$ Penjelasan tersebut senada dengan yang dijelaskan oleh Achmad Syaifuddin dalam skripsinya yang berjudul "Makna Simbol dalam Arsitektur Masjid Jamik Sumenep Madura Jawa Timur" bahwa masjid merupakan salah satu hasil karya budaya yang tidak saja sebagai tempat peribadatan, akan tetapi merupakan simbol dari peradaban Islam. ${ }^{18}$ Pada masa awal perkembangan Islam, masjid menjadi pusat peradaban sekaligus lembaga yang tidak dapat dipisahkan dari kehidupan masyarakat. Islam berkembang seiring dengan meningkatnya kesadaran masyarakat Islam memakmurkan masjid

12 Muhammad Mufti Filusuf, Skripsi "Sejarah dan Makna Arsitektur Masjid Jam'i Piti Muhammad Cheng Hoo Selaganggeng Mrebet Purbalingga ( 2005-2011)" (Purwokerto: IAIN Purwokerto, 2020), h. 3.

${ }^{13}$ Risca Damayanti, Masjid Jam"i Muhammad Cheng Hoo Purbalingga, Refleksi Alkulturasi Budaya pada masyarakat Purbalingga (Semarang: Universitas Semarang, 2016), h. 42.

${ }^{14}$ Filusuf, Skripsi "Sejarah dan Makna Arsitektur Masjid Jam'i Piti Muhammad Cheng Hoo Selaganggeng Mrebet Purbalingga (2005-2011), h. 17.

${ }^{15}$ A. Nur Zamzamniah, Andi Rifqah, dan Zulkarnain A, "Filosofi Penerapan Arsitektur Islam pada Masjid Agung Syekh Yusuf Gowa," TIMPALAJA Jurnal Dosen dan Mahasiswa Arsitektur Volume 1, Nomor 1 (2019), h. 71.

${ }^{16}$ Siti Umairoh dan Widyastuti Nurjayanti, "Kajian Seni Islam pada Masjid Hj. Sudalmiyah Rais Universitas Muhammadiyah Surakarta," SINETIKA Jurnal Arsitektur Vol. 15 No. 2 (Juli 2018), h. 57.

${ }^{17}$ Filusuf, Skripsi "Sejarah dan Makna Arsitektur Masjid Jam'i Piti Muhammad Cheng Hoo Selaganggeng Mrebet Purbalingga (2005-2011), h. 23.

${ }^{18}$ Achmad Syaifuddin, Skripsi “Makna Simbol dalam Arsitektur Masjid Jamik Sumenep Madura Jawa Timur” (Yogyakarta: UIN Sunan Kalijaga, 2020), h. xi.

Al Qalam: Jurnal Ilmiah Keagamaan dan Kemasyarakatan

Vol. 15, No. 1, Januari-Juni 2021 
dengan berbagai aktivitas sosial dan budaya. ${ }^{19}$ Masjid itu berarti suatu tempat melakukan segala aktivitas manusia yang mencerminkan nilai-nilai kepatuhan dan ketaatan kepada Allah. ${ }^{20}$ Selain itu, masjid bisa dipergunakan untuk kepentingan sosial. Misalnya sebagai tempat belajar dan mengajarkan kebaikan (menuntut ilmu), menyelesaikan hukum dan lain sebagaianya. ${ }^{21}$ Bahkan di masa lalu, masjid adalah kedudukan penguasa, untuk merundingkan masalah kenegaraan, menegakkan hukum dan markas perang. ${ }^{22}$ Masjid diibaratkan sebagai air hujan yang turun ditengah-tengah kemarau yang sangat panjang, sehingga masyarakat merasakan kehausan dan dahaga akan spiritual dan sosial kemasayarakatan. Di masjid kaum muslim mendapatkan ketentraman, kenyamanan, persaudaraan dan adab-adab yang menjadi kebutuhan dalam kehidupan. Ketaqwaan seseorang salah satunya bisa dilihat kehadirannya kemasjid. Masjid yang ramai oleh jama'ah didalamnya menunjukan bahwa masjid tersebut hidup dan menghidupkan. ${ }^{23}$

Sejalan dengan perkembangan zaman dan teknologi, munculnya banyak bangunan masjid merupakan hal yang positif, karena menunjukkan adanya kesadaran religius dikalangan umat Islam. Saat ini dapat dijumpai banyak masjid diberbagai tempat. Masjid-masjid saat ini mengalami perubahan yang sangat pesat terutama pada aspek bangunan. Bangunan masjid saat ini sangat megah dengan ornamen arsitektur yang indah dan teknologi yang modern, akan tetapi jika dicermati secara mendalam perubahan masjid hanya sebatas pada aspek luarnya saja, sedangkan aspek di dalamnya belum mengalami peruabahan yang berarti. Pada masa sekarang seiring dengan perkembangan Islam, perkembangan pendidikan Islam, perkembangan teknologi, perkembangan globalisasi, masjid dianggap sebagai tempat ibadah biasa. Di beberapa tempat, masjid menjadi sarana untuk menyampaikan dakwah, namun pada masa sekarang belum banyak yang mengetahui tentang masjid sebagai sumber pendidikan. Kebanyakan orang hanya mengetahui bahwa masjid hanyalah sarana, namun kurang mengetahui bahwa ada beberapa masjid yang dapat dijadikan sumber pendidikan melalui ornamen arsitektur ataupun pembiasaan-pembiasaan lainya. Masjid sebagai sumber pendidikan melalui gaya arsitektur ataupun semacamnya menjadi sangat unik untuk di cermati. Yang biasanya masjid hanya menjadi sarana ibadah umat Islam, ada bebrapa masjid yang mampu menjadi sumber pendidikan Islam itu sendiri. Salah satunya Masjid Pusaka As Su'ada yang memiliki nilai historis yang cukup tinggi terkait penyebaran agama Islam di Desa Waringin.

Masjid Pusaka As Su'ada lebih dikenal dengan sebutan "Masjid Lancip" merupakan salah satu masjid tertua dan bersejarah yang ada di Kabupaten Hulu Sungai Utara, tepatnya di Desa Waringin, Kecamatan Haur Gading yang selama ini tidak banyak diketahui masyarakat Kalimantan Selatan lantaran lokasinya yang agak

${ }^{19}$ M. Sofyan Alnashr, "Ornamen Masjid Jami Kajen serta Kontribusinya dalam Penguatan Pendidikan Karakter di Madrasah Ibtidaiyah,” Elementary Vol. 6 No. 1 (Juni 2020), h. 10.

${ }^{20}$ Uma Dewaji, Skripsi “Kajian Ragam, Bentuk Estetik, dan Makna Simbolik Ornamen pada Masjid Gedhe Kauman Keraton Yogyakarta” (Semarang: Universitas Negeri Semarang, 2019), h. 20.

${ }^{21}$ Atika, Skripsi "Makna Simbolik Arsitektur Masjid Agung Sang Cipta Rasa Sebagai Media Dakwah pada Masyarakat Cirebon” (Purwokerto: IAIN Purwokerto, 2020), h. 2.

${ }_{22}$ Mukhlis Peeni, Sejarah Kebudayaan Indonesia: Arsitektur (Jakarta: Raja Grafindo Persada, 2009), h. 239.

${ }^{23}$ Mohamad Aminudin, Tesis "Pendidikan Islam Berbasis Masjid Baitul Arqam Studi Kasus di Komplek Perumahan Griya Satria Indah Ii Sumampir” (Purwokerto: IAIN Purwokerto, 2020), h. 1.

Al Qalam: Jurnal Ilmiah Keagamaan dan Kemasyarakatan

Vol. 15, No. 1, Januari-Juni 2021 
terpencil. Masjid Pusaka As Su'ada telah masuk cagar budaya, namun belum banyak yang mengetahui sejarah masjid bahkan sebenarnya ada nilai-nilai pendidikan Islam dan dakwah Islamiyah yang terdapat pada ornamen arsitektur masjid tersebut.

Berdasarkan latar belakang masalah yang telah dikemukakan, maka dengan menariknya sejarah, ciri khas dan nilai historis dari Masjid Pusaka As Su'ada serta adanya nilai-nilai pendidikan Islam yang ada di Masjid Pusaka As Su'ada perlu dan menarik untuk dilakukan sebuah penelitian. Oleh karena itu, penelitian ini merupakan upaya untuk menjelaskan pada masyarakat mengenai nilai-nilai pendidikan Islam pada ornamen arsitektur Masjid Pusaka As Su'ada yang akan dituangkan peneliti dalam sebuah artikel jurnal.

\section{METODE}

Penelitian ini dilaksanakan di Masjid Assu'ada (Masjid Lancip) yang berada di Desa Waringin Kecamatan Haur Gading Kabupaten Hulu Sungai Utara Provinsi Kalimatan Selatan Indonesia dengan subjek penelitian adalah sebagian pengelola masjid dan sesepuh yang dianggap lebih mengetahui tentang masjid Assu'ada. Adapun jenis penelitian ini merupakan penelitian deskriptif dengan metode kualitatif. Metode kualitatif merupakan metode penelitian yang menghasilkan data deskriptif berupa katakata tertulis atau kesan dari orang dan perilaku yang dapat diamati. Oleh karena itu, hasil dari data penelitian lebih berkenaan dengan suatu penafsiran terhadap data yang ditemukan di lapangan. ${ }^{24}$ Prosedur pengumpulan data merupakan langkah atau cara yang paling relevan untuk mendapatkan data dalam penelitian. Adapun upaya untuk mengumpulkan data, peneliti menggunakan teknik observasi, wawancara, dan dokumentasi. Teknik analisis data dalam penelitian ini menggunakan reduksi data, penyajian data, dan penarikan kesimpulan. Kegiatan dalam analisis data kualitatif dilakukan secara berkesinambungan sampai tuntas sehingga datanya sudah jenuh. ${ }^{25}$ Kemudian peneliti melakukan pengecekan keabsahan data untuk mengurangi terjadinya kesalahan data dengan cara melakukan ketekunan pengamatan dan triangulasi.

\section{HASIL DAN PEMBAHASAN}

\section{Sejarah Masjid Pusaka As Su'ada Waringin (Masjid Lancip)}

\section{Lokasi dan Lingkungan}

Seperti kebanyakan bangunan-bangunan lain di Kalimantan Selatan, masjid ini terletak di tepi sungai, karena alat transportasi lewat sungai masa lalu sangat dominan. Bahkan konsentrasi penduduk pun berada pada lini sepanjang sungai. Masjid Pusaka As Su'ada pun terletak di tepi sungai di Desa Waringin Kecamatan Haur Gading Kabupaten Hulu Sungai Utara. Sebelah Barat sungai Negara/Tabalong, sebelah Timur terletak sawah, sedangkan sebelah Utara dan Selatan adalah rumah penduduk. Mata pencaharian yang utama adalah bertani serta agama penduduk desa tersebut $100 \%$ Islam. Selain itu terdapat sebuah pesantren kurang lebih 300 meter ke Selatan masjid.

\footnotetext{
24 Sugiyono, Metode Penelitian Pendidikan (Pendekatan Kuantitatif, Kualitatif, dan R\&D) (Bandung: Alfabeta, 2018), h. 14.

${ }^{25}$ Sugiyono, h. 337.
}

Al Qalam: Jurnal Ilmiah Keagamaan dan Kemasyarakatan

Vol. 15, No. 1, Januari-Juni 2021 


\section{Riwayat Singkat Berdirinya}

Sumber tertulis sebenarnya tidak ada, hanya dari cerita lisan pengelola masjid. Masjid Pusaka As Su'ada adalah salah satu masjid tertua dan bersejarah yang berada di Hulu Sungai, tepatnya di Desa Waringin Kecamatan Haur Gading Kabupaten Hulu Sungai Utara Provinsi Kalimantan Selatan. Asal nama "Waringin" sendiri diambil dari satu istilah yaitu kata Wara' yang artinya orangorang saleh yang apik dalam hal ilmu agama. Masjid ini diperkirakan berdiri pada tahun 1886M oleh seorang ulama berasal dari Alabio yang bernama K.H Abdul Ghani. Makamnya terletak tidak begitu jauh dari masjid dalam sebuah kubah dengan kijing/batur penuh ukiran.

Menurut versi lain sebagaimana terdapat dalam laporan pendokumentasian Masjid Assu'ada yang dilaksanakan oleh Bidang Permuseuman dan Kepurbakalaan Kanwil Depdikbud Provinsi Kalsel tahun 1987, masjid ini diperkirakan dibangun pada tahun 1886. Perkiraan ini didasarkan kepada inskripsi dengan aksara arab melayu pada cungkup makam salah seorang ulama sekaligus pendiri masjid yakni H. Abdul Gani di Kampung Teluk Keramat. Pada kubah tertulis: Almarhum Syeikh Haji Abdul Gani wafat 15-4-1336 H, 19-1-1916 M. Kalau yang bersangkutan meninggal dalam usia 70 tahun, aktif membangun masjid dalam usia 40 tahun maka diperkirakan masjid berdiri pada tahun $1886 \mathrm{M}$.

Informasi lain menyatakan bangunan masjid di lokasi sekarang merupakan pindahan dari lokasi pertama yang berada di pinggir sungai Waringin (aliran Sungai Hanyar cabang Sungai Tabalong) yang terancam longsor berada persis di arah barat depan masjid sekarang (versi lain menyatakan lokasi pertama berada di seberang sungai). Berdasarkan keterangan tersebut, dapat diperkirakan bahwa masjid pertama kali dibangun sekitar tahun 1886 dengan lokasi di pinggir sungai Waringin. Karena pondasi masjid runtuh/lonsor akibat abrasi sungai, maka sekitar tahun 1901 bangunan masjid dibongkar dan dipindah ke lokasi sekarang, tidak jauh dari lokasi pertama.

Bangunan pertama yang semula bertipe lantai panggung, ketika dibangun kembali di lokasi kedua lantainya tidak lagi ulin melainkan dengan tehel (ubin) yang didatangkan dari Singapura. Pada waktu itu, sebagian penduduk Waringin dan sekitarnya ada yang berprofesi sebagai pedagang antar pulau. Mereka berlayar hingga sampai ke pulau Jawa, Sumatera, bahkan Singapura dan Semenanjung Malaya, sehingga ketika kembali ke kampung halaman mereka membawa barang dagangan, atau bahan yang diperlukan untuk pembangunan masjid seperti ubin, dan lain sebagainya.

Selain tokoh ulama dan sekaligus pendiri masjid yakni H. Abdul Gani (asal kelahiran Alabio), tokoh ulama lainnya yang berperan terhadap masjid ini adalah H. Nawawi, H. Durahman, dan H. Marhusin di Waringin, serta H. Mahmudin dari Tengkawang. Mereka adalah juga tokoh ulama yang berperan penting dalam kegiatan ibadah sholat, pengajian, dan dakwah kepada masyarakat Waringi, Haur Gading, Tengkawang, dan sekitarnya.

Masjid ini merupakan masjid tertua dan satu-satunya di Waringin, dan Haur Gading. Waringin, dahulunya terdiri dari berbagai desa seperti Waringin, Tengkawang, Teluk Haur, dan Tuhuran. Sedangkan Haur Gading juga terdiri dari beberapa desa yakni Haur Gading, Keramat, Jingah Bujur, Pulutan, dan Tambak

Al Qalam: Jurnal Ilmiah Keagamaan dan Kemasyarakatan

Vol. 15, No. 1, Januari-Juni 2021 
Sari Panji. Waringin dan Haur Gading, dahulunya hanya punya satu masjid yakni Masjid Assu'ada Waringin.

Masyarakat desa-desa itu selalu menjalankan ibadah sholat Jumat di masjid ini. Bahkan di sinilah tempat dilaksanakan mengaji duduk, yang mana para jamah pengajian dari beberapa kampung dan bahkan konon dari kampung Negara datang ke Waringin dengan perahu tambangan untuk mengaji di Waringin yang saat itu tekenal memiliki ulama besar seperti halnya H. Abdul Gani. Oleh karena itu, ada yang mengaitkan bahwa asal nama desa Waringin karena dahulunya desa ini tempat beradanya ulama-ulama yang Wara' yakni istilah bagi ulama yang apik dalam melaksanakan ibadah. Ada pula yang mengatakan bahwa dinamakan Waringin karena dahulunya di tepian sungai Waring ini tumbuh pohon beringin.

Pada saat didirikan untuk pertama kalinya dan ketika bangunan masjid ini dipindah ke lokasi sekarang ini, masjid ini dahulunya bernama Masjid Assuhada. Penamaan itu mungkin berkaitan dengan usaha para pendiri masjid yang berdakwah menyebarkan Islam di daerah Waringin dan sekitarnya dan mendirikan masjid di sini. Perjuangan mereka dianggap jihad fii sabilillah dan mereka yang berada di jalan itu disebut sebagai syuhada atau syahid.

Kini masjid ini dinamakan Masjid Assu'ada. Assu'ada berasal dari kata Su'ada artinya "beruntung". Perubahan nama dari Assuhada menjadi Assu'ada menurut informasi H. Abdul Wahab (63 tahun) terjadi pada tahun 1965-an, yakni pada saat panitia masjid diketuai oleh $\mathrm{H}$. Abdurrahman, seorang ulama lulusan Pesantren Gontor Ponorogo. Tidak diketahui secara pasti latar belakang perubahan nama tersebut.

Setelah sekian lama berdiri dan seiring semakin tuanya kondisi fisik masjid serta pertambahan jamaah masjid sehingga bangunan masjid tidak lagi mampu menampung jamaah sholat jumat, maka pada tahun 1970-an dilaksanakan renovasi oleh panitia masjid. Nama-nama panitia masjid saat itu antara lain: $H$. Asnawi, H. Syahdan, H. Husin, H. Tarman, Sar'ie. Renovasi dilakukan dengan memperluas bangunan induk dengan mengganti dinding dengan kayu ulin, serta memperluas ruang mikrab dengan bangunan beton. Meski ruang mikrab diperluas, model kubahnya tetap seperti semula yakni kubah model bawang dengan pataka.

Sehubungan atap masjid banyak yang telah bocor, maka pada tahun 2009 dilakukan lagi renovasi dengan mengganti atap sirap dengan atap metal zincalum/roof. Pada saat penggantian inilah, beberapa hiasan ujung talang atap masjid (simbar, cabang) yang ada pada ketiga tingkatan atap masjid, dilepas atau tidak dikembalikan ke posisi semula.

Hiasan sejenis jamang (rumbai pilis, buntut hayam) pada Masjid Assu'ada Waringin yang lazim di sebut simbar, dapat dilihat pada atap Masjid Su,ada di desa Wasah Hilir Kabupaten Hulu Sungai Selatan, pada Masjid Syekh Abdul Hamid Abulung Sungai Batang, Martapura, Kabupaten Banjar, dan pada Masjid Quba di Amawang Kanan, Kabupaten Hulu Sungai Selatan (kini sudah tidak ada lagi, dan hanya dapat dilihat pada foto masjid sebelum mengalami renovasi).

Pada tahun 2010, kembali dilakukan pemugaran dengan mengganti bahan kayu sintok pada kubah bangunan induk menjadi kayu balangiran, serta 
membeton bangunan mikrab dan mengganti kubah migrab dengan bahan baru, meski bentuk kubahnya masih dipertahankan.

Bulan April 2012, masjid ini kembali direnovasi dengan cara meninggikan lantai masjid, namun ubin tua tetap dipertahan. Peninggian lantai dilakukan karena sebelumnya telah pernah terjadi banjir pasang yang nyaris menenggelamkan lantai masjid. Biaya meninggikan lantai masjid ini ditanggung sepenuhnya oleh warga keturunan Banjar asal Johor Malaysia, yang orang tuanya dahulu berasal dari desa Waringin.

Pada tahun 2019-2020, masjid kembali dienovasi dengan menambah kubah dan menara serta memperluas halaman pada masjid yang berbahan semen dan keramik. Selain itu, terdapat beberapa pohon kurma yang ditanam di halaman masjid tersebut. Pengurus Masjid Gusti Mastur mengatakan usia masjid yang sudah berumur ini menjadi salah satu daya tarik bagi warga baik dari dalam maupun luat daerah. "Sampai saat ini masjid As Su'ada masih aktif digunakan, warga biasa menyebut masjid ini dengan sebutan Masjid Lancip," ujarnya.

\section{Kepengurusan dan Kegiatan Masjid Pusaka As Su'ada Waringin (Masjid Lancip)}

Berdasarkan hasil rapat/pertemuan pada hari Sabtu tanggal 5 Januari 2019 yang dihadiri oleh tokoh agama dan tutuha masyarakat yang memutuskan bahwa pengurus Masjid Pusaka As Su'ada Waringin adalah sebagai berikut :

Tabel 1. Kepengurusan Masjid Pusaka As Su'ada Waringin

\begin{tabular}{|c|l|l|}
\hline No. & \multicolumn{1}{|c|}{ Jabatan/Kedudukan } & \multicolumn{1}{c|}{ Nama } \\
\hline 1 & Pembina dan Pelindung & Kepala Desa Waringin \\
\hline 2 & Penasihat & $\begin{array}{l}\text { H. Abdul Wahab } \\
\text { H. Fandi } \\
\text { H. Barkati }\end{array}$ \\
\hline 3 & Ketua & H. Gusti Mastur \\
\hline 4 & Sekretaris & H. Murhan \\
\hline 5 & Bendahara & H. Sam'ani \\
\hline 6 & Seksi Keamanan & $\begin{array}{l}\text { Buseri } \\
\text { Hamrani } \\
\text { Abdullah }\end{array}$ \\
\hline 7 & Seksi Pemeliharaan dan Kebersihan & M. Luthfi \\
\hline 8 & Seksi Hari Besar Islam & $\begin{array}{l}\text { H. Husaini } \\
\text { Ilyas } \\
\text { Raili }\end{array}$ \\
\hline 9 & Imam Masjid & $\begin{array}{l}\text { H. Tarman } \\
\text { H. Astani }\end{array}$ \\
\hline
\end{tabular}

Al Qalam: Jurnal Ilmiah Keagamaan dan Kemasyarakatan

Vol. 15, No. 1, Januari-Juni 2021 


\begin{tabular}{|l|l|l|}
\hline \multirow{10}{*}{10} & & H. Husni \\
& & H.Hadrian \\
& Kaum Masjid & H. Sar'i \\
& & H. Abdul Wahab \\
& & Ahmad Rauyani \\
\hline \multirow{3}{*}{} & & Utih \\
& & Muni \\
& & Utur \\
& Aini Karim \\
& Hadrian \\
& Ahmad Tabsi \\
& H. Hamdan \\
& M. Luthfi \\
\hline
\end{tabular}

(Sumber : Dokumentasi, 23 November 2020)

Kegiatan Rutin Masjid Pusaka As Su'ada Waringin adalah sebagai berikut :

Tabel 2. Kegiatan Rutin Masjid Pusaka As Su'ada Waringin

\begin{tabular}{|l|l|}
\hline Malam Senin & Pengajian Pemuda \\
\hline Selasa & Latihan Habsy Remaja Puteri \\
\hline Rabu & Latihan Habsyi Pemuda \\
\hline Kamis & Latihan Habsyi Pemuda \\
\hline Malam Jum'at & Kegiatan Agama \\
\hline Sabtu & Pengajian Bapak/Ibu di Desa Waringin \\
\hline Malam Ahad & Habsyi Pemuda \\
\hline
\end{tabular}

(Sumber : Dokumentasi, 23 November 2020)

\section{Ornamen Arsitektur Masjid Pusaka As Su'ada Waringin (Masjid Lancip)}

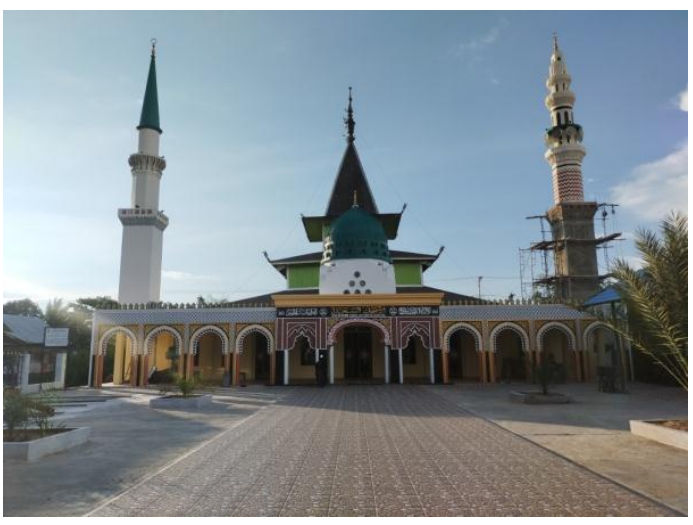

Tampilan Depan Masjid Pusaka As Su'ada

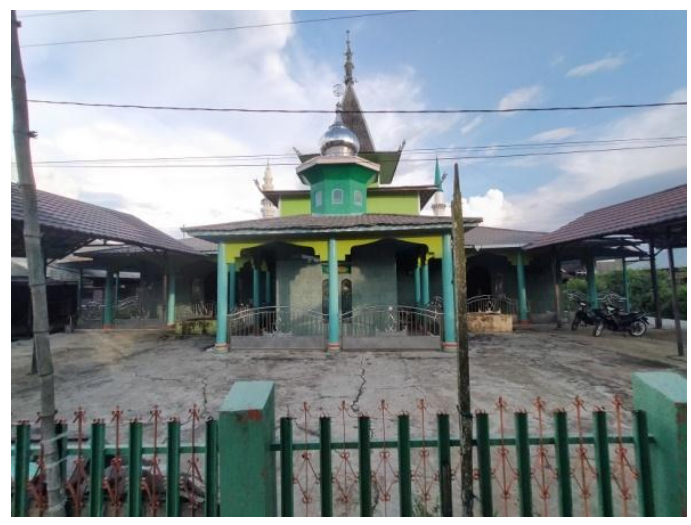

Tampilan Belakang Masjid Pusaka As

Al Qalam: Jurnal Ilmiah Keagamaan dan Kemasyarakatan

Vol. 15, No. 1, Januari-Juni 2021 
Waringin

(Sumber : Dokumentasi, 20 November 2020)
Su'ada Waringin

(Sumber : Dokumentasi, 20 November 2020)

Masjid merupakan wujud dari perkembangan Islam di Indonesia. Makna dan fungsi masjid sebagai bangunan rumah ibadah dan juga merupakan bagian dari perkembangan agama Islam di Indonesia dapat dilihat dari ornamen arsitektur masjid tersebut. Unsur utama yang dipakai untuk membedakan bentuk atau gaya bangunan masjid adalah atap, menara, dan pola hiasan. Bentuk atap bangunan masjid yang ada di Kalimantan Selatan mempunyai perbedaan dengan masjid tradisional Indonesia lainnya, meski sama-sama beratap tumpang (bertingkat). Perbedaan yang menonjol adalah dari segi variasi bentuk atap, ukiran atau ragam hias (ornamen) karena masing-masing dipengaruhi oleh budaya dan lingkungan setempat.

Di Kalimantan Selatan, masjid yang berarsitektur tradisional atap tumpang yang bercirikan budaya Banjar kini tinggal sedikit tersisa. Hal ini disebabkan oleh sebagian besar bangunan telah direnovasi ke bentuk baru atau modern dengan atap/kubah model bawang. Akan tetapi, masih ada masjid dengan ciri khas budaya Banjar salah satunya adalah Masjid Pusaka As Su'ada.

Masjid Pusaka As Su'ada lebih dikenal dengan sebutan "Masjid Lancip" merupakan salah satu masjid tertua yang ada di yang terletak di Desa Waringin Kecamatan Haur Gading Kabupaten Hulu Sungai Utara Provinsi Kalimantan Selatan yang selama ini tidak banyak diketahui masyarakat lantaran lokasinya yang agak terpencil. Masjid tersebut telah masuk cagar budaya yang dilindungi sesuai UndangUndang Republik Indonesia Nomor 11 Tahun 2010 tentang Cagar Budaya. Arsitektur Masjid Pusaka As Su'ada mempunyai keunikan tersendiri yang membedakan dengan masjid lainnya. Beberapa ornamen yang ada di Masjid Pusaka As Su'ada Desa waringin Kecamatan Haur Gading Kabupaten Hulu Sungai Utara (HSU) masih dalam bentuk aslinya.

Secara umum, Masjid Pusaka As Su'ada memilki dua bagian utama, yaitu bagian luar masjid dan bagian dalam masjid. Pada bagian luar, masjid Pusaka As Su'ada memiliki bagian-bagian yang memiliki karakteristik dan ciri khas tertentu, di antaranya :

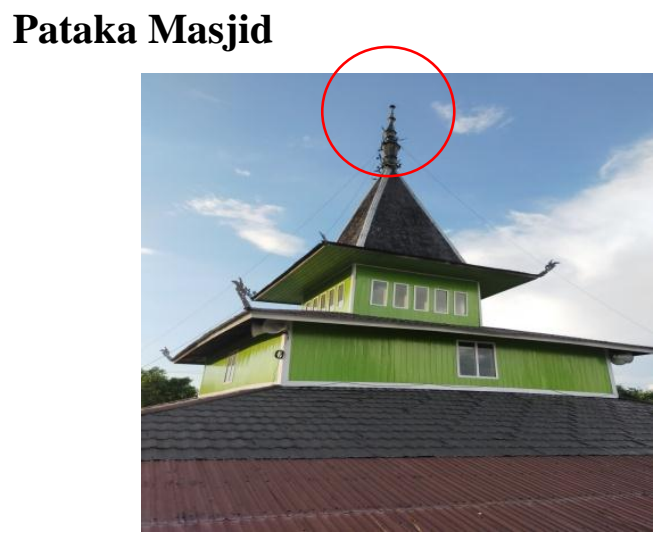

(Sumber : Dokumentasi, 20 November 2020)

Pataka atau mahkota pada ujung atap masjid merupakan ornamen pelengkap sekaligus memiliki makna yang sangat dalam serta menambah keindahan pada

Al Qalam: Jurnal Ilmiah Keagamaan dan Kemasyarakatan

Vol. 15, No. 1, Januari-Juni 2021 
bangunan masjid tersebut.$^{26}$ Pataka atau mahkota pada bangunan Masjid Pusaka As Su'ada terbuat dari logam dan dibentuk sedemikian rupa dengan motif hiasanhiasan.

\section{Tingkatan Atap Masjid}

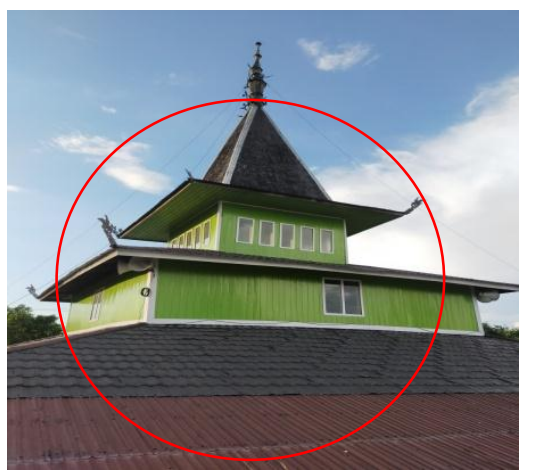

(Sumber : Dokumentasi, 20 November 2020)

Atap masjid merupakan komponen utama yang harus ada. Sebab dari sisi pragmatisnya sebagai pelindung dari panas dan hujan, sekaligus sebagai faktor pendukung kenyamanan umat Islam berada di dalam masjid. Sama dengan masjid itu sendiri, atap masjid sebagai komponen utama juga memiliki sejarah, budaya, dan maknanya sendiri. ${ }^{27}$ Atap adalah bagian dari suatu bangunan yang berfungsi sebagai penutup seluruh ruangan yang ada di bawahnya terhadap pengaruh hujan, panas, debu, angin, dan sebagainya atau juga untuk keperluan perlindungan dan sebagai memperindah bangunan supaya terlihat menarik dan sempurna pembuatannya. ${ }^{28}$ Atap berposisi di bagian paling atas yang mampu memberikan ciri tersendiri pada masjid, apalgi jika bentuk dan warna yang ditonjolkan jauh berbeda dengan yang lain. ${ }^{29}$

Atap masjid berbentuk tumpang (meru) dan tebuat dari sirap. Atap mempunyai tiga tingkatan, yang mana tingkatan paling atas sangat lancip. Hal tersebut merupakan ciri khas Kalimantan Selatan seperti Masjid Kuno Sungai Batang, Martapura, Masjid Su'ada, Wasah Hilir Kandangan, dan Masjid Pusaka Banua Lawas Tabalong. ${ }^{30}$ Atap tumpang merupakan atap yang bersusun semakin ke atas semakin kecil, tingkat paling atas berbentuk limas. Jumlah tumpag itu selalu ganjil, biasanya 3 sampai 5 tingkat. Adapun Masjid Pusaka As Su'ada mempunyai 3 tingkatan atap masjid.

${ }^{26}$ Sholikhin, Skripsi "Nilai-Nilai Pendidikan Islam dalam Gaya Arsitektur Masjid Pathok Negoro Sulthoni dan Eksistensinya Pada Remaja Sekitar di Plosokuning Yogyakarta,” h. 69.

${ }^{27}$ Ahmad Sugeng Riady, "Masjid dan Ragam Atapnya," 5 Oktober 2018, alif.id.

28 "Pengetian Atap dan Jenis-Jenisnya," 8 Desember 2018, gedungarsitektur.

${ }^{29}$ Amelia Vina, Hunian Tampil Memukau dengan Atap dan Kanopi (Yogyakarta: Noktah, 2019), h. 7 .

${ }^{30}$ Bidang Permuseuman dan Kepurbakalaan, Laporan Pendokumentasian Masjid Assu'ada Desa Waringin Kabupaten Hulu Sungai Utara (Kalimantan Selatan: Kantor Wilayah Depdikbud Provinsi Kalimantan Selatan, 1987), h. 2.

Al Qalam: Jurnal Ilmiah Keagamaan dan Kemasyarakatan

Vol. 15, No. 1, Januari-Juni 2021 


\section{Jendela Masjid}

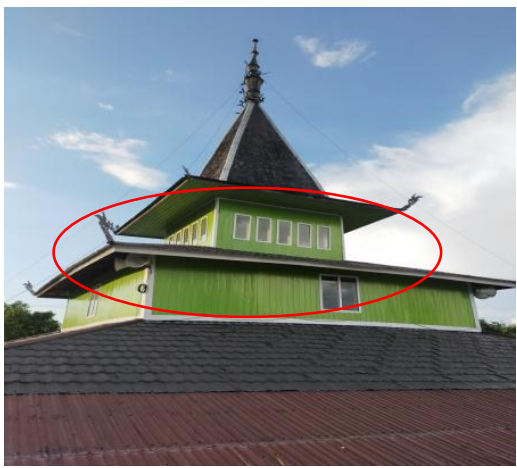

(Sumber : Dokumentasi, 20 November 2020)

Jendela adalah bagian bangunan yang transparan dan dapat dibuka untuk pertukaran udara atau dapat didefinisikan sebagai lubang yang dapat diberi penutup, biasanya dipasang pada dinding atau tempat yang kurang cahaya dan udara. Jendela biasanya berbentuk segitiga, persegi, persegi panjang, atau bentuk tak beraturan. ${ }^{31}$

Jendela pada Masjid Pusaka As Su'ada terbuat dari bahan kaca dan berbentuk persegi panjang yang berjumlah 20 buah pada tingkatan kedua dan 8 buah pada tingkatan pertama.

\section{Pintu Masjid}

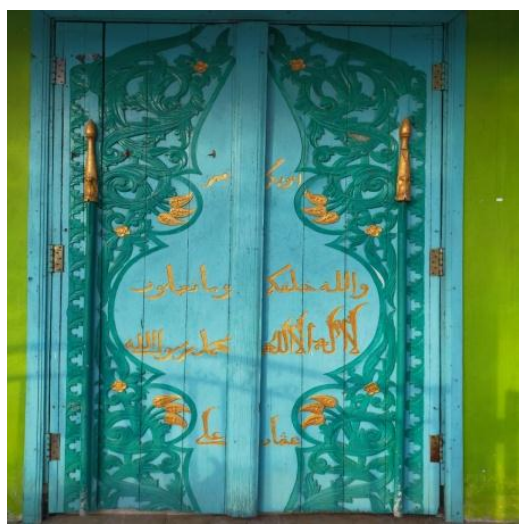

(Sumber : Dokumentasi, 20 November 2020)

Pintu merupakan bagian masjid yang sangat penting, pintu merupakan tempat lalu lintas keluar masuknya orang-orang ke Masjid untuk melaksanakan shalat. $^{32}$

Pintu pada masjid pusaka As Su'ada keseluruhannya berjumlah 9 buah. Akan tetapi hanya 7 pintu yang sering dibuka. Beberapa pintu memiliki ornamen indah berupa ukiran kaligrafi yang bertuliskan ayat Alquran surah Ash-Shafat : 96

\footnotetext{
31 "Pertanyaan - Wikipedia Bahasa Indonesia," diakses 21 Oktober 2020, id.m.wikipedia.

${ }^{32}$ Sundari dan Yulimarni, "Estetik Ornamen Masjid di Kota Padang,” h. 6.
}

Al Qalam: Jurnal Ilmiah Keagamaan dan Kemasyarakatan

Vol. 15, No. 1, Januari-Juni 2021 


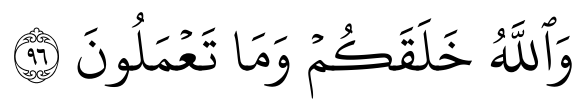

Artinya : "Padahal Allah-lah yang menciptakan kamu dan apa yang kamu perbuat itu". (QS. Ash-Shafat : 96)

\section{Kolam Depan Masjid}

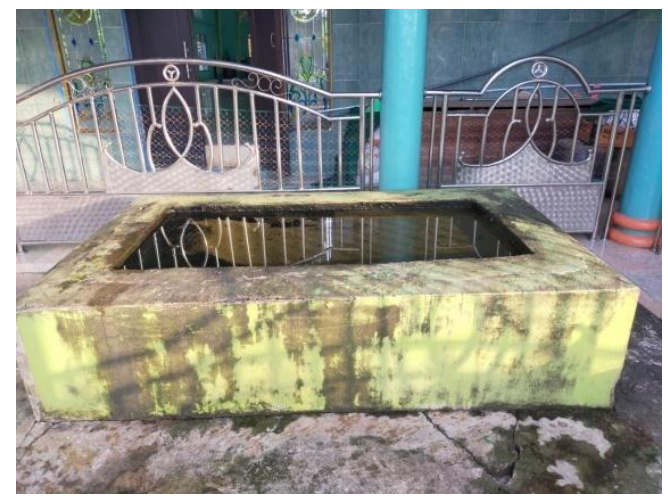

(Sumber : Dokumentasi, 20 November 2020)

Kolam adalah genangan air yang kondisinya dapat dikendalikan. Biasanya kolah terbuat dari tanah, tembok, atau beton. ${ }^{33}$ Kolam yang ada pada Masjid Pusaka As Su'ada berjumlah 2 buah kolam yang berbentuk persegi panjang dengan kedalaman 2 meter. Kolam tersebut biasanya digunakan untuk mengambil air wudhu.

\section{Bedug Masjid}

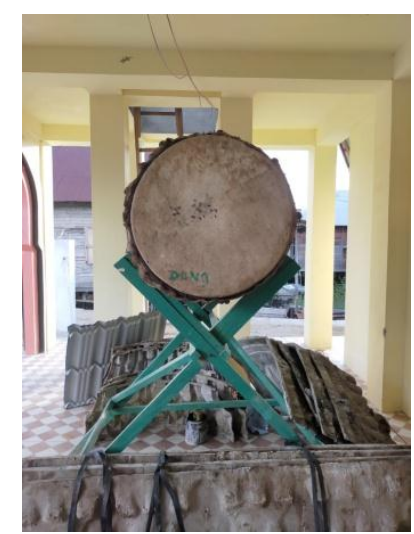

(Sumber : Dokumentasi, 20 November 2020)

Bedug merupakan salah satu alat yang penting sebagai panggilan untuk melaksanakan shalat di masjid. Namun seiring berkembangnya zaman, bedug

${ }^{33}$ Khairuman dan Khairul Amri, Pembersihan \& Pembesaran Gurami Secara Intensif (Jakarta: Agro Media Pusaka, 2005), h. 23.

Al Qalam: Jurnal Ilmiah Keagamaan dan Kemasyarakatan

Vol. 15, No. 1, Januari-Juni 2021 
sebagai sarana untuk panggilan shalat semakin terpinggirkan. Hal ini dikarenakan terdapat alat lain yang lebih mudah dan praktis penggunaannya.$^{34}$

Bedug yang terdapat pada masjid pusaka As Su'ada ini diletakkan di teras masjid. Bedug ini merupakan salah satu benda peninggalan tertua yang berada di masjid tersebut. Bedug ini digunakan sebagai pertanda bahwa shalat fardhu telah tiba sebelum adzan dikumandangkan. Bedug tersebut terbuat dari kulit sapi. Sekarang, bedug sering digunakan ketika shalat Jum'at.

Kemudian pada bagian dalam, masjid Pusaka As Su'ada juga memiliki bagian yang menonjol dan memiliki ciri khas yaitu :

\section{Tiang Guru Masjid}

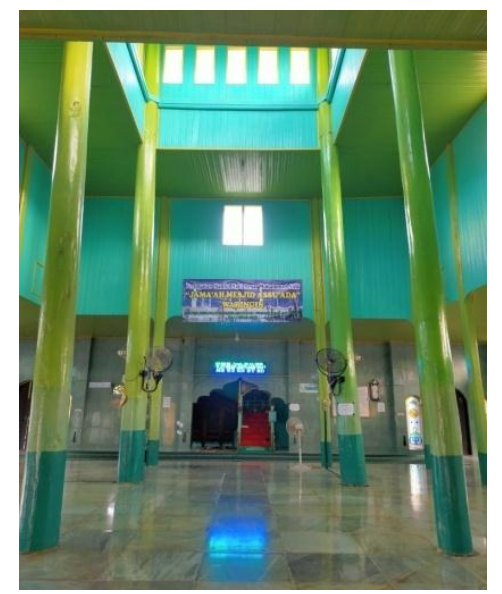

(Sumber : Dokumentasi, 20 November 2020)

Tiang pada sebuah bangunan berfungsi untuk menyokong atau menyangga atap dan lantai bangunan ${ }^{35}$. Bentuk tiang sangat beragam, seperti tiang yang terdapat pada bangunan Masjid Pusaka As Su'ada. Terdapat tiang penyangga yang berada di tengah bangunan utama masjid dan merupakan kayu asli sejak didirikan, ada 4 tiang utama yang biasa disebut tiang guru, ditambah dengan tiang bantu yang berada disekitar tiang utama yang berjumlah 12 buah dan 20 tiang dekat dengan dinding mengelilingi ruang utama.

\footnotetext{
34 Masmedia Pinem, "Sejarah Masjid Al-Falah Kiai Modjo Tondano-Sulawesi Utara," Tsaqofah: Jurnal Agama dan Budaya Vol. 13, No. 1 (Juni 2015), h. 10.

35 Sundari dan Yulimarni, "Estetik Ornamen Masjid di Kota Padang," h. 6.

Al Qalam: Jurnal Ilmiah Keagamaan dan Kemasyarakatan

Vol. 15, No. 1, Januari-Juni 2021
} 


\section{Tingkatan Tangga Mimbar}

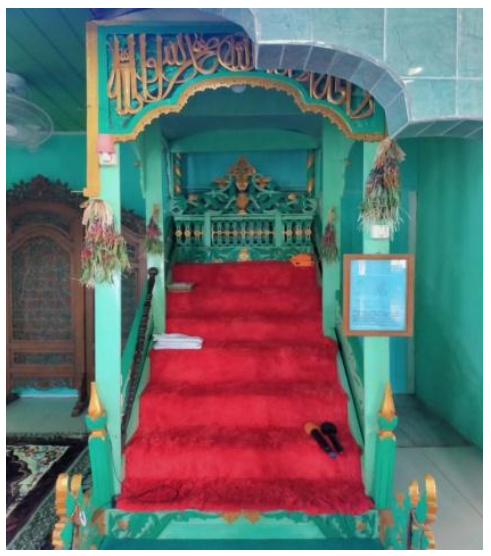

(Sumber : Dokumentasi, 20 November 2020)

Mimbar atau minbar adalah platform di dalam masjid dimana imam shalat berdiri untuk memberi khutbah Jum'at dan juga khutbah Idul Fiti serta Idul Adha. Mimbar yang tinggi membolehkan imam melihat jamaah yang ramai ${ }^{36}$. Mimbar pada masjid pusaka As Su'ada dirancang khusus dengan 7 tingkatan anak tangga yang dilapisi dengan kain yang berwarna merah sehingga terkesan mewah. Mimbar selalu dihias dengan bunga yang jarang kosong karena beberapa jamaah yang datang ke masjid ini sering membawa bunga dan menggantungkan di sekitar mimbar.

\section{Tiang Mimbar}

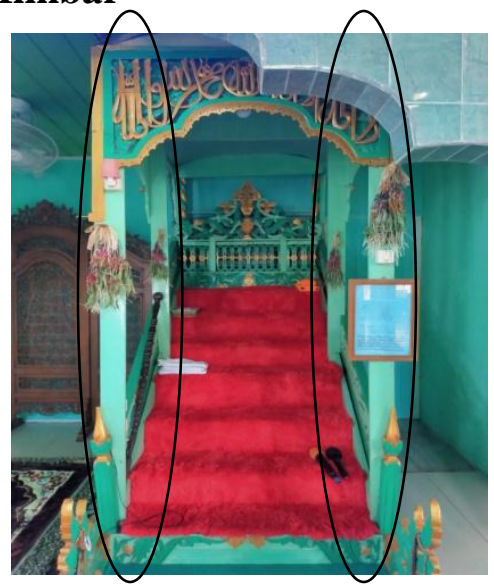

(Sumber : Dokumentasi, 20 November 2020)

Tiang mimbar merupakan penyangga atau penopang mimbar itu sendiri agar tetap tegak berdiri. ${ }^{37}$ Tiang mimbar merupakan bagian dari pada mimbar Yusuf Gowa," h. 78.

${ }^{37}$ Ilmanda Tegar Irianta Mahusfah, Muhammad Ainun Najib, dan Sutriani, "Identifikasi Wujud Akulturasi Budaya Terhadap Arsitektur Masjid Al-Hilal Tua Katangka," TIMPALAJA Jurnal Dosen dan Mahasiswa Arsitektur Vol. 1, No. 1 (2019), h. 13.

Al Qalam: Jurnal Ilmiah Keagamaan dan Kemasyarakatan

Vol. 15, No. 1, Januari-Juni 2021 
berjumlah 6 buah yang terbuat dari kayu ulin yang ada pada sisi kanan dan kiri mimbar dan berfungsi sebagai penyangga mimbar tersebut.

\section{Karawang/Hiasan Masjid}

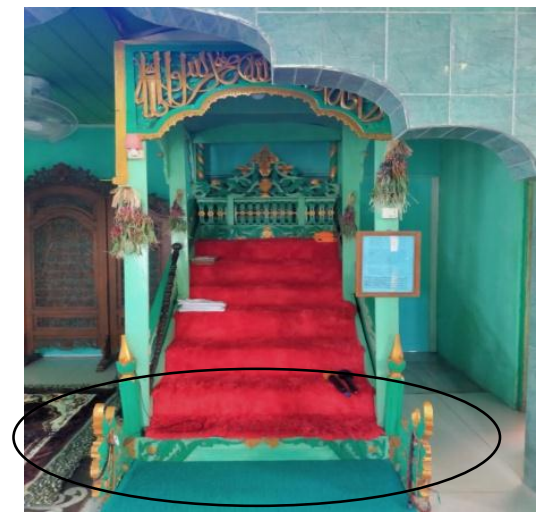

(Sumber : Dokumentasi, 20 November 2020)

Karawang atau disebut juga hiasan terbuat dari kayu ulin yang diukir menggunakan pahat sehingga membentuk karya seni yang sangat estetik. Karawang atau hiasan merupakan elemen pelengkap agar suatu karya seni terlihat indah.

Masjid-masjid kuno di Indonesia menunjukan beberapa keistimewaan, diantaranya denah berbentuk persegi empat atau bujur sangkar dengan bagian kaki yang tinggi serta pejal, atap bertumpang tiga, lima bahkan lebih. Kemudian dikelilingi parit atau kolam air pada bagian depan atau sampignya, dan memiliki serambi. Mustaka pada puncak atap ketiga masjid memberikan simbolisasi bahwa Tuhan sang Pencipta merupakan dzat yang tinggi dan penciptaan seluruh alam serta benda yang ada berada dibawah kreasinya. Sehingga ia tidak terikat oleh dzat yang diciptakanya, tidak terikat oleh waktu, materi, dan ruang ${ }^{38}$.

\section{Nilai-Nilai Pendidikan Islam pada Ornamen Arsitektur Masjid Pusaka As Su'ada Waringin (Masjid Lancip)}

\section{Pataka Masjid}

Pataka disebut juga sebagai mahkota pada bangunan masjid yang terbuat dari logam dan dibentuk sedemikian rupa dengan motif hiasan-hiasan. Pada ornamen tersebut memilili simbol suatu kedudukan yang tinggi, yakni bermakna angka satu atau huruf alif yang melambangkan ke-Esaan Tuhan.

Seiring dengan berjalannya waktu, ornamen tersebut pernah mengalami kerusakan yang disebabkan oleh terpaan angin yang kencang sehingga harus direnovasi kembali tanpa mengubah keaslian dari bentuk awal ornamen yang telah ada.

\footnotetext{
2007), h. 305.

Al Qalam: Jurnal Ilmiah Keagamaan dan Kemasyarakatan

Vol. 15, No. 1, Januari-Juni 2021
}

${ }^{38}$ Badri Yatim, Sejarah Peradaban Islam, Dirasah Islamiyah II (Jakarta: Rajagrafindo Persada, 


\section{Tingkatan Atap Masjid}

Pada umumnya, sebuah bangunan mempunyai atap. Atap merupakan komponen utama dari bangunan masjid, tidak terkecuali pada Masjid Pusaka As Su'ada. Pada zaman dahulu, atap masjid terbuat dari sirap yang berbahan dasar kayu ulin karena kayu ulin dapat menyerap panas sehingga ruangan masjid tersebut menjadi nyaman dan sejuk. Seiring berjalannya waktu, atap yang awalnya sirap diubah menjadi berbahan seng. Hal ini dikarenakan sirap sangat sulit ditemukan dan harganya sangat mahal serta perenovasiannya memakan waktu yang relatif lama, sedangkan bahan seng mudah ditemukan dan harganya cukup terjangkau.

Atap pada Masjid Pusaka As Su'ada mempunyai 3 tingkatan, yang setiap tingkatannya mempunyai makna. Tingkatan pertama bermakna sebagai hak Adam. Tingkatan kedua bermakna hak Muhammad. Tingkatan ketiga bermakna hak Allah Swt. Namun, hal tersebut hanyalah suatu pandangan hakikat sebagai kebesaran Allah Swt.

\section{Jendela Masjid}

Jendela pada Masjid Pusaka As Su'ada terbuat dari bahan kaca dan berbentuk persegi panjang yang berjumlah 20 buah pada tingkatan kedua dan 8 buah pada tingkatan pertama. Jendela berfungsi sebagai masuknya nur atau cahaya yang menerangi ruangan dalam masjid. Jendela tersebut tidak pernah mengalami perubahan dari awal dibangun sampai sekarang.

Jendela masjid yang berjumlah 20 buah pada tingkatan kedua mempunyai makna 20 sifat Allah Swt. dalam empat mata penjuru. Sedangkan 8 buah jendela masjid pada tingkatan pertama bermakna 8 pancar mata angin.

\section{Pintu Masjid}

Pintu pada Masjid Pusaka As Su'ada terbuat dari kayu ulin. Pintu masjid keseluruhannya berjumlah 9 buah. Akan tetapi hanya 7 pintu yang sering dibuka. Pintu tersebut mempunyai makna 7 pintu surga. Beberapa pintu memiliki ornamen indah berupa ukiran kaligrafi bertuliskan ayat Alquran surah Ash-Shafat : 96 yang mempunyai makna rahasia bagi yang mengetahuinya dalam pandangan ma'rifat.

Pada awal pembangunannya, masjid memiliki 8 buah pintu. Namun, beberapa pintu mengalami kerusakan yang mengharuskannya untuk diganti secara bertahap. Selanjutnya, pintu belakang masjid yang awalnya 2 buah ditambah 1 buah sehingga menjadi 3 buah yang bertujuan untuk memudahan jamaah masuk ke dalam ruangan masjid. Hingga sekarang, hanya menyisakan 2 pintu yang masih asli.

\section{Kolam Depan Masjid}

Kolam yang ada pada Masjid Pusaka As Su'ada berjumlah 2 buah kolam yang berbentuk persegi panjang dengan kedalaman 2 meter. Kolam tersebut biasanya digunakan untuk mengambil air wudhu dan mempunyai makna sebagai pancar/jalan ilmu yaitu ilmu hikmah dan ilmu laduni. 
Menurut pandangan syari'at, berwudhu merupakan suatu jalan untuk mensucikan diri dari segi zhahinya. Namun dari pandangan hakikat, untuk mendapatkan suatu ilmu, baik itu ilmu hikmah atau ilmu laduni, maka perlu membersihkan wadah daripada ilmu tersebut yaitu hati.

\section{Bedug Masjid}

Bedug pada Masjid Pusaka As Su'ada terbuat dari kayu ulin dan kulit sapi yang sudah dikeringkan. Biasanya, bedug digunakan sebagai penanda tibanya waktu shalat, berbuka puasa, imsak, keadaan darurat, mengumpulkan masyarakat, dan sebagainya.

\section{Tiang Guru Masjid}

Tiang merupakan penyangga atap dan lantai pada bangunan masjid. Tiang pada Masjid Pusaka As Su'ada keseluruhannya berjumlah 40 buah yang terbuat dari kayu ulin. 4 buah tiang utama disebut dengan tiang guru yang berfungsi sebagai fondasi utama bangunan masjid. Oleh karena itu mempunyai banyak makna rahasia. Salah satunya yaitu bermakna sahabat Nabi Muhammad Saw. yang 4 yakni Abu Bakar Ash-Shiddiq, Umar bin Khattab, Utsman bin'Affan, dan Ali bin Abi Thalib.

Asal mula kayu ulin yang dijadikan sebagai tiang pada masjid tersebut berasal dari daerah Barito yang kemudian dibawa melalui jalur sungai dengan cara ditarik mudik ke Hulu Sungai hingga didirikan dan dibangun sebuah masjid.

\section{Tingkatan Tangga Mimbar}

Mimbar merupakan tempat khatib yang biasanya melakukan khotbah. Mimbar tersebut terbuat dari kayu ulin dengan ukiran-ukiran yang sarat akan sebuah makna. Salah satunya, pada tingkatan tangga mimbar yang berjumlah 7 dan setiap anak tangga mempunyai makna yang diibaratkan dengan tingkatan langit.

\section{Tiang Mimbar}

Tiang mimbar merupakan bagian daripada mimbar yang berjumlah 6 buah terbuat dari kayu ulin dan mempunyai makna Rukun Iman. Selain itu, fungsi dari tiang mimbar adalah untuk meletakkan harum-haruman seperti bunga/kambang.

\section{Karawang/Hiasan Masjid}

Karawang atau hiasan terbuat dari kayu ulin yang diukir menggunakan pahat dari keterampilan seorang seniman yang mempunyai banyak makna rahasia. Salah satunya diumpamakan sebagai kakambangan yakni buah daripada ilmu yang dipelajari selama mengaji duduk di masjid tersebut. Karawang atau hiasan yang masih ada serta paling menonjol dari segi keunikannya terdapat pada mimbar yang bermakna layaknya seorang yang berdo'a menadahkan tangan sambil memegang tasbih.

\section{KESIMPULAN}

Al Qalam: Jurnal Ilmiah Keagamaan dan Kemasyarakatan

Vol. 15, No. 1, Januari-Juni 2021 
Masjid Pusaka As Su'ada adalah salah satu masjid bersejarah yang sarat akan makna dalam pandangan ilmu agama yang mempunyai masing-masing rahasia pada setiap ornamen arsitektur masjidnya yang meliputi sifat kesempurnaan.

Masjid mempunyai peranan yang sangat penting dalam hal kegiatan belajar ilmu agama. Di samping letaknya yang sangat strategis di pinggiran sungai, pada zaman dahulu orang biasanya hanya menggunakan perahu/sampan sebagai alat transportasi untuk pergi ke tempat tujuan.

Adapun nilai-nilai pendidikan Islam yang diajarkan adalah ilmu syari'at, ilmu tareqat, ilmu hakikat, dan ilmu ma'rifat yang beri'tikadkan Ahlu Sunnah wal Jama'ah dengan madzhab Imam Syafi'i.

Keunikan masjid yang dibangun adalah hasil dari tafakkur pada diri seseorang sehingga memusyahadahkannya pada pandangan hingga mencapai syukur pada kenyataan. Hal yang demikian itu merupakan atas kebesaran Allah Swt. dengan sebab Nabi Muhammad Saw.

Sebuah karya yang dibangun tentu mempunyai makna yang besar di dalamnya, maka dari itu peninggalan orang-orang terdahulu haruslah tetap dirawat dan dijaga nilainilai pendidikan Islamnya, karena itulah sebenar-benarnya warisan yang mengandung ilmu kesempurnaan.

\section{DAFTAR PUSTAKA}

Alfirah, Nunung Dewi, Fadhilah Aliyyah Rasyid, dan Wasilah. "Seni Hias Bangunan Bersejarah Masjid Lompoe Urwatul Wudska Maros." TIMPALAJA Jurnal Dosen dan Mahasiswa Arsitektur Volume 1, Nomor 2 (2019): 122-31.

Alnashr, M. Sofyan. "Ornamen Masjid Jami Kajen serta Kontribusinya dalam Penguatan Pendidikan Karakter di Madrasah Ibtidaiyah.” Elementary Vol. 6 No. 1 (Juni 2020).

Aminudin, Mohamad. Tesis "Pendidikan Islam Berbasis Masjid Baitul Arqam Studi Kasus di Komplek Perumahan Griya Satria Indah Ii Sumampir.” Purwokerto: IAIN Purwokerto, 2020.

Aryadi, Mirda, Asril S, dan Febri Yulika. "Ornamen Masjid Asasi Sigando Kota Padangpanjang.” Gorga : Jurnal Seni Rupa Vol. 09 No. 01 (Juni 2020).

Atika. Skripsi "Makna Simbolik Arsitektur Masjid Agung Sang Cipta Rasa Sebagai Media Dakwah pada Masyarakat Cirebon.” Purwokerto: IAIN Purwokerto, 2020.

Bidang Permuseuman dan Kepurbakalaan. Laporan Pendokumentasian Masjid Assu'ada Desa Waringin Kabupaten Hulu Sungai Utara. Kalimantan Selatan: Kantor Wilayah Depdikbud Provinsi Kalimantan Selatan, 1987.

Damayanti, Risca. Masjid Jam"i Muhammad Cheng Hoo Purbalingga, Refleksi Alkulturasi Budaya pada masyarakat Purbalingga. Semarang: Universitas Semarang, 2016.

Dewaji, Uma. Skripsi “Kajian Ragam, Bentuk Estetik, dan Makna Simbolik Ornamen pada Masjid Gedhe Kauman Keraton Yogyakarta." Semarang: Universitas Negeri Semarang, 2019.

Al Qalam: Jurnal Ilmiah Keagamaan dan Kemasyarakatan

Vol. 15, No. 1, Januari-Juni 2021 
Filusuf, Muhammad Mufti. Skripsi "Sejarah dan Makna Arsitektur Masjid Jam'i Piti Muhammad Cheng Hoo Selaganggeng Mrebet Purbalingga ( 2005-2011 ).” Purwokerto: IAIN Purwokerto, 2020.

Gustami. Nukilan Seni Ornamen Indonesia. Yogyakarta: Institut Seni Indonesia, 2008.

Khairuman, dan Khairul Amri. Pembersihan \& Pembesaran Gurami Secara Intensif. Jakarta: Agro Media Pusaka, 2005.

Mahusfah, Ilmanda Tegar Irianta, Muhammad Ainun Najib, dan Sutriani. "Identifikasi Wujud Akulturasi Budaya Terhadap Arsitektur Masjid Al-Hilal Tua Katangka." TIMPALAJA Jurnal Dosen dan Mahasiswa Arsitektur Vol. 1, No. 1 (2019).

Peeni, Mukhlis. Sejarah Kebudayaan Indonesia: Arsitektur. Jakarta: Raja Grafindo Persada, 2009.

"Pengetian Atap dan Jenis-Jenisnya," 8 Desember 2018. gedungarsitektur.

“Pertanyaan - Wikipedia Bahasa Indonesia.” Diakses 21 Oktober 2020. id.m.wikipedia.

Pinem, Masmedia. "Sejarah Masjid Al-Falah Kiai Modjo Tondano-Sulawesi Utara." Tsaqofah: Jurnal Agama dan Budaya Vol. 13, No. 1 (Juni 2015).

Putra, Eko Roy Ardian. Skripsi "Makna Simbolis pada Ragam Hias Masjid Mantingan di Jepara.” Surakarta: Institut Seni Indonesia, 2018.

Riady, Ahmad Sugeng. "Masjid dan Ragam Atapnya," 5 Oktober 2018. alif.id.

Sholikhin, Rahmad. Skripsi "Nilai-Nilai Pendidikan Islam dalam Gaya Arsitektur Masjid Pathok Negoro Sulthoni dan Eksistensinya Pada Remaja Sekitar di Plosokuning Yogyakarta." Yogyakarta: Fakultas Ilmu Agama Islam Universitas Islam Indonesia, 2020.

Sugiyono. Metode Penelitian Pendidikan (Pendekatan Kuantitatif, Kualitatif, dan $R \& D)$. Bandung: Alfabeta, 2018.

Sundari, Sri, dan Yulimarni. "Estetik Ornamen Masjid di Kota Padang." Jurnal Seni Desain Dan Budaya Vol. 5, No. 2 (2020).

Supatmo, dan Syafii. "Nilai Multukultural Ornamen Tradisional Masjid-Masjid Warisan Para Wali di Pesisir Utara Jawa.” Jurnal Imajinasi Vol. XIII No. 2 (Juli 2019).

Supriyadi, Bambang. "Kajian Ornamen pada Mesjid Bersejarah Kawasan Pantura Jawa Tengah.” ENCLOSURE : Jurnal Ilmiah Perancangan Kota dan Permukiman Vol. 7 No. 2 (2018).

Syaifuddin, Achmad. Skripsi "Makna Simbol dalam Arsitektur Masjid Jamik Sumenep Madura Jawa Timur.” Yogyakarta: UIN Sunan Kalijaga, 2020.

Umairoh, Siti, dan Widyastuti Nurjayanti. "Kajian Seni Islam pada Masjid $\mathrm{Hj}$. Sudalmiyah Rais Universitas Muhammadiyah Surakarta." SINETIKA Jurnal Arsitektur Vol. 15 No. 2 (Juli 2018).

Vina, Amelia. Hunian Tampil Memukau dengan Atap dan Kanopi. Yogyakarta: Noktah, 2019. 
Wajidi. "Ragam Arsitektur Masjid Tradisional Banjar Kalimantan Selatan dan Makna Simbolisnya." Jurnal Kebijakan Pembangunan Vol. 12, No. 2 (Desember 2017): 149-61.

Yatim, Badri. Sejarah Peradaban Islam, Dirasah Islamiyah II. Jakarta: Rajagrafindo Persada, 2007.

Zamzamniah, A. Nur, Andi Rifqah, dan Zulkarnain A. "Filosofi Penerapan Arsitektur Islam pada Masjid Agung Syekh Yusuf Gowa." TIMPALAJA Jurnal Dosen dan Mahasiswa Arsitektur Volume 1, Nomor 1 (2019): 70-81. 